\title{
Historiallinen murros ja aikuiskasvatuksen tutkimus
}

\author{
RISTO RINNE
}

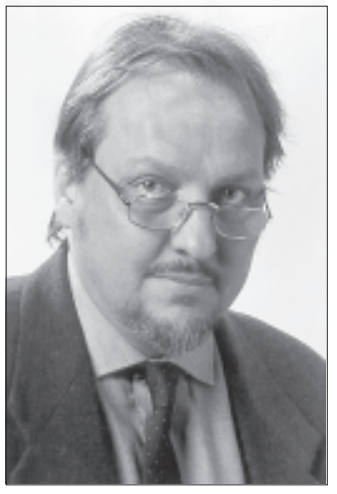

"Aikuiskoulutuksesta tai oikeammin elinikäisestä oppimisesta on tullut koulutuspolitiikan ja kasvatuksen kärkihanke niin maailmalla ja ylikansallisissa järjestöissä kuin Suomessa. Keskeisenä osana tietotalouden ydintä, oppivaa yhteiskuntaa, oppivaa tiesmitä oppiminen nähdään rajattomana mahdollisuutena. Yksi asia on hukassa. Miten tämä maailmankaikkeuden uusi utopia toteutuu? Jos tieteen ja tutkimuksen tehtävänä on paljastaa todellisuus naamioiden, lupausten ja toiveiden alta, tulee meidän näyttää, onko aikuiskasvatuksen keisarilla vaatteet yllään", kirjoittaa professori Risto Rinne.

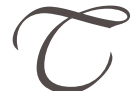

ieteeltä ja tutkimukselta totuuden paljastaminen edellyttää sitä, ettemme sokeasti sitoudu kukoistaviin poliittisiin kehittämis- ja parannuspuhetapoihin ja ole maksettuina taputtajina vahvistamassa niiden yksittäisiä harhoja ja virhepäätelmiä. Aikuiskasvatustutkijoiden tehtävänä olisi nähdä ja näyttää, mitä aikuiskoulutuksen ja elinikäisen oppimisen liturgian alla todella tapahtuu. Tämä edellyttää tutkijoilta päättäväistä mieltä ja lujaa rohkeutta sijoittaa aikuiskasvatus yhteiskunnallisiin ja historiallisiin kehyksiinsä sekä laajakatseisuutta nähdä Suomi osana muuttuvan Euroopan ja maailman sosiaalisia ja ideologisia valtarakenteita.

\section{Juuriltaan irronnut?}

Viisitoista vuotta on kulunut siitä, kun kirjoitin nykyistä nuorempana tutkijana yhdessä kollegani kanssa suoranimikkeisen artikkelin "Mitä aikuiskasvatustutkimus on?" tähän samaiseen Aikuiskasvatus-lehteen (Rinne \& Kivinen 1995). Tuolloin totesimme Tapio Vahervaan $(1986,490)$ viitaten, että aikuiskoulutuksen tutkimus oli vielä paljolti "lapsen kengissään" ja mm. Odd Nordhaugiin (1986) viitaten, että sitä hallitsee yhdenlainen "käsitteellinen erämaa", "heikko varustus", "miltei ole- mattomuus", "horjuvuus" ja "tarkoitushakuisuus". Aikuiskasvatus-lehden tuolloinen toimitus merkitsi tuohon kohtaan artikkeliamme alaviitteen, jossa kertoi näkemyksemme suomalaisen aikuiskasvatustutkimuksen teoriapohjan niukkuudesta "käyvän dialogia muiden näkemysten kanssa". Näin tuolloin. Mikähän on tilanne nyt?

Artikkelimme perustui tuolloin suomalaista aikuiskoulutusta koskevan tutkimuksen historialliseen aineistoon ja sen analyysiin (ks. Vanttaja 1993). Väitimme aineiston pohjalta, että tutkimus oli halunnut yhtäältä ylläpitää vapaan kansansivistystyön perinnettä, mutta toisaalta yhä lisääntyvästi kiinnittynyt ammatilliseen aikuiskoulutukseen. Kiinnostuksen kohteeksi oli selvityksen mukaan kohonnut vahvasti myös oppimisprosessien ja opinkäynnin psykologisten ja didaktisten seikkojen tarkastelu. Me puolestamme liputimme vahvasti sen puolesta, että tutkimuksen pitäisi entistä vahvemmin tutkia myös "aikuiskoulutuksen yhteiskunnallisia yhteyksiä taloudesta politiikkaan".

Vaikka puolitoista vuosikymmentä on suhteellisen pitkä aika ja suomalaista tutkimus- ja tiedepolitiikaa on tuona aikana reivattu kohden uusia ulapoita, rohkenen väittää, että tuo analyysi ei ole vanhentunut. Jos mahdollista, näköpiirissä tuolloin olleet trendit ovat lähinnä voimistuneet. Ai- 
kuiskasvatustutkimuksen kenttää on alkanut jäännöksettä läpäistä hyödyn, sovellutusten ja välittömän tulosvastuun taakka. Ammatillisen aikuiskasvatuksen tutkimus on laajentunut vauhdilla muun muassa "soveltavaa tutkimusta" harjoittavien ammattikorkeakoulujen kasvaneiden resurssien valtavan potentiaalin myötä. Samoin on käynyt erityyppisen oppimisprosessien ja opetuksen psykologisen ja didaktisen tutkimuksen suhteen. Erityisen nopeasti on kasvanut ja paikkansa vakiinnuttanut nopeatempoinen kehittämis- ja kokeilutoiminta pyrkien nojaamaan asemansa tutkimuksen suoman legitimiteetin varaan. Tämä toiminta, joka ainoastaan ohuin säikein koskettaa tutkimuksen rajapintaa, sijaitsee tosiasiassa yleisimmin kehittämis- ja politiikkatoiminnan kentällä, vaikka sitä tutkimukseksi onkin tahdottu kutsua.

Käynnissä on aikuiskoulutustutkimuksen etenevä "fragmentoituminen", kuten Anja Heikkinen (2007) osuvasti kehitystä kuvaa. Tässä fragmentoitumisessa on kyse näkökulman kadottamisesta. Tutkimus on yhtäältä sirpaloitumassa ja toisaalta suurista retorisista lupauksista huolimatta työntymässä aiempaa vähäpätöisempään asemaan. Tutkimusta ollaan laajasti oksastamassa varsin hyötytavoitteisesti yhdenlaisiksi "inhimillisten voimavarojen hyödyntämishankkeiksi" kirjavina Human-Resource-Development -projekteina, yrittäjyyskasvatusyrityksinä ja henkilöstökoulutusstrategioina. Kenelläkään ei ole kokonaisuutta hallinnassaan. Vakavasti otettavan laaja-alaisen ja kauaskantoisen perustutkimuksen asema ei ole kadehdittava ja ylipäätään tutkimuksen ja kehittämisen välistä rajankäyntiä ei juuri tahdota käydä.

OECD:hen ja Euroopan Unioniin liittymisten ja suhteiden syvenemisen myötä aikuiskoulutustutkimuksen painopistettä on yhä ylikansallisemmin suunnattu ammatilliseen koulutukseen. Ammatillisesta aikuiskoulutuksesta taas näyttää Suomessa 1990-luvulta lähtien tulleen entistä voimakkaammin tuloksellisuuden ja kilpailukyvyn lisäämisen väline. Koulutuksesta itsestäänkin on tullut markkinatavaraa, jota myydään ja ostetaan samoin periaattein kuin mitä tahansa kaupallista tuotetta. Markkinahenkisyyden aalto, joka on kulkenut läpi koko suomalaisen koulutuspolitiikan koulutusjärjestelmän kaikilla tasoilla, on jättänyt oman leimansa myös aikuiskoulutukseen ja sen tutkimuksen suuntautumiseen. (Rinne 2003 b)

2000-luvun koulutuskeskustelussa vilahtelee jatkuvasti yritysmaailmasta tuttuja käsitteitä. Koulutuksen kentillä astelevat opiskelijoiden ja opet- tajien sijasta asiakkaat ja palvelujen tuottajat. Arvioinnin kohteeksi ovat nousseet koulutuksen tehokkuus, vaikuttavuus ja laatu. Julkisenkin sektorin rahoittamassa aikuiskoulutuksessa tulosajattelu on lyönyt itsensä läpi. Vaikka usko koulutuksen kaikinpuoliseen hyödyllisyyteen on edelleenkin vankka, halutaan tuon uskon vakuudeksi nyt myös konkreettista evidenssiä - selvää näyttöä toiminnan tuloksista ja tehokkuudesta. Hyvät tavoitteet ja komea retoriikka eivät enää riitä oppilaitosten ja kurssien olemassaolon oikeutukseksi. Aikuiskoulutuksen ja elinikäisen oppimisen on oltava jäännöksettä hyödyllistä ja se pitää pystyä osoittamaan erinäisin näytöin, esityksin ja sepittein. Vaarana tällaisessa esitystalouden performanssissa saattaa olla perustutkimuksen ja pitkäjänteisten tutkimushankkeiden rappio. Tällaisen kehityksen seurauksena senkaltainen aikuiskoulutustutkimus voi yhä voimistua, joka suoraan ja kyselemättä parhaiten ja nopeiten palvelee annettuja koulutus- ja henkilöstöpoliittisia tarkoitusperiä - ja niitäkin vain lyhyellä aikavälillä.

Perin harvassa ovat ne tutkimukset, jotka kykenisivät jäljittämään aikuiskasvatustutkimuksen kunniakkaimpia perinteitä ja arvostusta. Onko enää mahdollista ja toivottavaa tuottaa esimerkiksi senkaltaisia tutkimuksia kuin Kosti Huuhkan (1955) kirjoittama alan ensimmäinen väitöskirja "Talonpoikaisnuorison koulutie - tutkimus talonpoikaisnuorison koulunkäynnistä ja siihen vaikuttaneista sosiaalisista tekijöistä Suomessa 1910-1950". Onko meillä kykyä ja tahtoa tehdä alan klassista perustutkimusta, joka keskittyisi "kasvatuksen ja yhteiskuntaelämän väliseen sidonnaisuuteen" ja siihen peruskysymykseen, "miten yhteiskuntaelämä vaikuttaa kasvatukseen". Ja pystyisimmekö sellaiseen tieteidenvälisyyteen kuin aikuis- ja nuorisotutkimuksen uranuurtaja, tohtori Huuhka, jonka tutkimusta ohjasivat Heikki Waris sosiaalipolitiikan ja Urpo Harva kansansivistysopin ja filosofian piiristä ja jonka esitarkastajina toimivat Aimo Halila historian ja Erik Allardt sosiologian piiristä, kaikki maamme eturivin tiedemiehiä (mts. 3, 1112). Aikuiskasvatustutkimus on valtavirraltaan irronnut tärkeästä perinteisestä yhteydestään yhteiskuntatieteisiin, mutta myös humanistisiin tieteisiin.

Kansansivistysoppi syntyi ja juurtui viime vuosisadalla alleviivatusti osaksi Yhteiskunnallista korkeakoulua. Tämä yhteys oli varsin toinen kuin esimerkiksi kasvatusopilla, jonka synty nauliutui aina Turun Akatemiasta asti Helsingin Aleksante- 
rin yliopiston kautta aluksi oppikoulunopettajien ja sittemmin koko opettajankoulutuksen aputieteeksi kautta maan. Vaikka näinä aikoina tahdotaan poliittisen päättäväisesti torjua katsominen taustapeiliin, lienee sallittua katsoa puolen vuosisadan taakse näin Aikuiskasvatuksen Tutkimusseuran 70-vuotisjuhlavuonna. Ilman historiallista tajuntaa on mahdotonta ymmärtää olevaa ja tulevaa. Jo aikuiskasvatustutkimuksen perinnekin velvoittaa meitä aikuiskoulutuksen tutkijoita tähän.

\section{Aikuiskoulutus ja sen tutkimus - yhtä ja samaa retoriikkaa?}

Aikuiskoulutustutkimusta ja sen mahdollisuuksia tässä maailmassa ei ole syytä tarkastella vain sen omalla eristäytyneellä kentällään. Se tulisi paikantaa osana sitä yhteiskunnallista ja kulttuurista maailmaa, jossa aikuiset ihmiset elävät. Olisi tarkasteltava niitä haasteita, jotka nousevat aikuisten elämänolosuhteiden muutoksista ja harjoitetun talous-, yhteiskunta- ja koulutuspolitiikan murroksista. Aikuiskoulutuksen tutkijoina meidän tulisi alati olla hereillä ja kyetä analysoimaan, tulkitsemaan, ymmärtämään, mutta myös aistimaan, haistamaan ja maistamaan niitä jatkuvasti laajenevia globaaleja ja lokaaleja trendejä, jotka uudella vuosituhannella muovaavat aikuisväestön kasvuympäristöä, sen rajoja ja mahdollisuuksia.

1990-luvun jaettu suomalainen kokemus oli kansallisen historiamme syvin lamakausi ja sen pitkään kestänyt jälkihoito. Tämä kokemus limittyi aikuiskoulutuksen uudentyyppisten markkinavetoisempien mallien sisäänajoon. Varsin luontevaa noissa oloissa oli, että niin aikuiskoulutukselle kuin aikuiskoulutustutkimukselle riitti kysyntää. Suurin paine ja samalla merkittävin retorinen lupaus kohdentui aikuiskoulutukseen työttömyydenhoitokeinona. Työvoimapoliittinen aikuiskoulutus kohosi arvoon arvaamattomaan, sen taloudellinen resurssointi kasvoi ja etenkin työministeriö suolsi seurantatutkimuksia toimintansa tuloksellisuudesta, joita voisi näin päivinä kutsua "evidence based" ja oli osoittavinaan investointien kannattavuuden. Mutta samaan aikaan kohosi esiin myös kriittisen aikuiskoulutustutkimuksen ääni. Työvoimapoliittista aikuiskoulutusta alettiin kritikoida enemmänkin työvoiman varastointina ja työvoimatilastojen siivoajana kuin työttömyyden, etenkään pitkäaikaistyöttömyyden torjujana ja yhteiskunnallisen rakennemuutoksen hallinnan keinona.

Samankaltainen aikuiskoulutuksen ja aikuiskou- lutustutkimuksen sosiaalinen tilaus on edessämme nyt 2000-luvun ensi vuosikymmenen lopulla, maailmanlaajuisen finanssikriisin jälkihoidossa. 1990-luvun opetuksista voitaneen, kovista väittelyistä huolimatta, oppia se, että työvoimapoliittisella aikuiskoulutuksella oli paitsi vahva sosiaalinen tilauksensa myös eittämätön vaikutuksensa. Tuo vaikutus ei ehkä niinkään tai ensisijassa osunut siihen, että koulutuksen avulla maahan olisi luotu työpaikkoja, pystytty parantamaan työvoiman tarjonnan ja kysynnän yhteenosumista tai työllistetty pysyväisluonteisesti joukkomitoin työttömiä. Ikävä kyllä vaikutus ei liene tuonkaltainen nytkään. Vaikutus oli ja on ehkä myös nyt pikemminkin se, että työmarkkinoilta syrjäytymisen ja laajemmankin sosiaalisen osattomuuden kierteeseen tuotiin ainakin joidenkin kohdalla vaihtelua, yhteisöllisyyttä ja jotakin ajankäyttöä jäntevöittävää tekemistä, ehkä rahtunen toivoakin, mielekkyyttä elämään. (ks. Ruoholinna \& Rinne 2001, 5-6; Järvinen \& Vanttaja 2001)

Tom Schuller (2004) on hyvin epäileväinen sen suhteen, että vaikka useimmat OECD:n jäsenmaat tukevat poliittisessa diskurssissaan ja retoriikassaan elinikäistä oppimista, onko elinikäisen oppimisen politiikka sittenkään kovin laajasti toteutunut ja viety läpi todellisessa politiikanteossa. OECD on asiasta laajemminkin huolissaan, mitä todentavat mm. senkaltaiset raportit kuin "Beyond Rhetoric" (OECD 2003). Useat tutkijat toteavatkin, ettei lopulta näytä olevan olemassakaan mitään kokonaisvaltaista kehystä tai tarkastelukulmaa, jonka kautta voitaisiin ymmärtää, mitä edistystä, jos mitään, elinikäisen oppimisen politiikan rintamalla on tapahtunut (Instance 2003; Coffield 2000; Schuller 2004). Aikuiskoulutuspolitiikan ja sen tutkimuksen arjessa eletään noidankehässä, jossa olemassa olevien aikuiskoulutusinstituutio- ja sektorirakenteiden välinen yhteistyö, poliittinen näkyvyys ja käytössä oleva data eivät kohtaa kuin sattumoisin siellä täällä. Näin ollen uudesta "elinikäisen oppimisen politiikasta" on vaikeaa tehdä sen paremmin politiikan kuin tutkimuksen keskeistä kenttää. Elinikäiseltä oppimiselta yksinkertaisesti näyttää puuttuvan institutionaalinen perusta, professionaalinen identiteetti, hallinnollinen sijainti ja poliittinen profiili. (Schuller 2004)

Vaikka myöntäisimmekin sen ilmiselvän tosiasian, että siirtyminen "elinikäisen oppimisen yhteiskuntaan" on suuressa määrin vain retoriikkaa, on mahdotonta kieltää, että tuo retoriikkaa tuottaa tästä huolimatta myös liikettä. Kuten Andy Green 
(2000) toteaa: "Life long learning is a powerful mobilising rhetoric...". Tuo retoriikka puhuu ja vakuuttaa tekijänsä ja tutkijansa lakkaamatta uudelleen ja uudelleen teknologian ja työorganisaatioiden muutoksesta, uudesta tietotaloudesta, lisääntyvästä vapaa-ajasta, elämänuran katkoksellisuudesta, väestön ikääntymisestä, työajan pidentämisen väistämättömyydestä ja globaalin taloudellisen kilpailun pakosta. Se takoo noiden ajatusten ja uskomusten väistämättömyyden osaksi tajuntaamme ja toimintaamme. Elinikäisestä oppimisesta - olkoon retoriikkaa tai ei - on tullut koulutusyhteiskunnan tai oikeammin "oppivan yhteiskunnan" mentaalinen ja toiminnallinen ydinpiste. Meille suomalaisille siitä on tullut korkean suomalaisen osaamistason ja maamme menestystarinan kiistattomasti jaettu tunnusmerkki sekä kunnon kansalaisuuden ja yksilöllisen pärjäämisen credo.

\section{Uusi Uljas Ihminen}

Stephen Ball $(2009,201)$ kirjoittaa erityisestä "elinikäisen oppimisen politiikkateollisuudesta", joka tuottaa lakkaamatta toistavaa retoriikkaa itsestään. Milloin elinikäinen oppiminen on taatuin avain menestykseen ja paras investointi inhimilliseen pääomaan, milloin varmin tae innovaatioiden ja luovuuden rohkaisemiseen tai täyden kansalaisuuden, sosiaalisen koheesion ja työllisyyden edistämiseen. Ballin mukaan tähän retoriikkaan on mukaan valjastettu kokonainen "politiikkakoneisto" erilaisia mekanismeja, toimenpiteitä ja taktiikoita elinikäisen oppimisen ohjelman läpimenon takaamiseksi. Kaiken tämän avulla ei tehdä yhtään enempää eikä vähempää kuin tuotetaan "uudenlaista ihmistä" ja "uutta ihmisyyden etiikkaa", jonka ytimenä on täydellisesti valmistaa "kustakin minästä yrittävä yksilö".

Tarkastellessaan elinikäisen oppimisen maailmaa artikkelissaan "Lifelong learning, subjectivity and the totally pedagogised society" Ball (2009) kiteyttää lopputulemansa neljään kohtaan:

Elinikäisen oppimisen maailmaa asuttavat oppijat, jotka ovat yksin ja yksinäisiä.

Tuo maailma on kaventuneen moraalisen vastuun ja syöpyvän luottamuksen maailma.

Oppivat ihmiset ovat tuossa maailmassa asiakkaita ja oppimiskokemukset markkinoiden kauppatavaroita.

- Tuon maailman arvottama elämäntyyli tukee keskiluokkaisia puheenaiheita ja keskiluok- kaa ja täten jälleenvahvistaa vanhoja eriarvoisuuksia ja jakoja sekä tuottaa uusia.

Tässä kaikessa on kyse syvällisestä episteemisestä siirtymästä modernista kasvatusparadigmasta jälkimoderniin kasvatusparadigmaan, joka pyrkii kaikin tavoin luomaan uusia joustavia, yksinäisiä, herkästi vastaanottavia ja vastuullisia oppijoita ja samalla esineellistämään sosiaalisen. Esille astuu tällöin Ballin $(2009,213)$ mukaan "vaarallinen itserakkaus" ja "ekonomistisen teorian territorio", jossa saatamme joutua työskentelemään ja elämään jatkuvan sattumanvaraisuuden määrittämässä riskien täyttämässä maailmassa.

Vaikka elinikäisen oppimisen sanoma on tullut valtavirraksi vasta muutama vuosikymmen sitten, on kestänyt jo kaksi vuosituhatta siitä, kun kreikkalaiset keksivät "paidean" idean elinikäisen koulutuksen lähtökohdaksi. Zygmunt Bauman (2005) tarkastelee uutta elinikäisen oppijan tarinaa "oppimisena kävelemään juoksuhiekalla”. Hän (mts. 1) vertaa aiempaa aikuiskoulutuksen maailman toimintaa ballistisiin ohjuksiin, jolloin ohjukset piti vielä etukäteen ohjelmoida kulkemaan kohden maalejaan. Elinikäisen oppimisen ideaa hän taas vertaa uusiin "viisaisiin ja älykkäisiin ohjuksiin", jotka osaavat muuttaa suuntaa matkansa varrella kohteensa liikkeiden mukaisesti. Älykkäät ohjukset toisin kuin vanhemmat ballistiset serkkunsa oppivat koko ajan matkallaan; niillä on kyky oppia nopeasti ja kyetä samalla unohtamaan ja tuhoamaan aiemmin oppimansa lentoradat.

Myös Bauman (2005, 9-11) näkee yhdeksi näiden "uusliberalismin ankarien aikojen" kaikkein merkittävimmäksi siirtymäksi uuden ihmisen muotoutumisen. Hänen mukaansa itseohjautuvan oppimisen jargoni vie meidät kohden keskustelua, joka sallii valtion luopuvan perinteisestä vastuustaan tuottaa laadukasta koulutusta kaikille kansalaisille, mikä on ollut demokraattisen yhteiskunnan peruspilari. Tällaisessa välinpitämättömyyden maisemassa on helppoa kokea olevansa eksyksissä ja toivottomuuden tilassa, missä lopulta mikään ei ole enää ennustettavissa ja kontrolloitavissa. Vastavoima tälle kaikelle voisi olla pyrkimys rakentaa autioitunutta julkista tilaa uudelleen ja suoda mahdollisuus kääntää omat yksilöllisesti koetut puutteet ja tarpeet yhteisesti jaetuiksi yhteiskunnallisiksi huoliksi ja toiminnoiksi.

Perustellusti voidaan puhua ylikansallisten järjestöjen - kuten OECD:n tai EU:n - "hegemonistisesta vallasta" ohjattaessa globaalia siirtymistä 
uuden uljaan ihmisen luomisen aikakauteen. Kaikkialla siirtymä aikuiskoulutuksen maailmasta elinikäisen oppimisen maailmaan tarkoittaa sitä, että oman inhimillisen pääoman säilyttäminen ja kehittäminen lankeaa yhä painavammin kunkin yksilön omille harteille. (Rubensson -; ks. Rinne 2008)

Muiden joukossa myös Colin Griffin (1999a; 1999b) kummastelee sitä voimaa, millä "elinikäisen oppimisen" käsite on vallannut alaa "aikuiskoulutuksen" käsitteeltä ja miten tämä uusi retorinen käänne luo uusia ajattelutapoja, toimintoja ja koulutuspolitiikkaa. Hän kysyy, mikä on ajanut koulutuksen ulos ja oppimisen sisään viime vuosien koulutuspoliittisessa diskurssissa. Hänen mukaansa takana on jonkinkaltainen myöntyminen sosiaalisen ja teknologisen muutoksen globaaliin väistämättömyyteen, jota koulutuspolitiikka on ikäänkuin "näkymättömän käden" otteessa pakotettu seuraamaan.

Käsitteellinen muutos luonnollisesti kytkeytyy hallitusten haluttomuuteen enää rahoittaa hyvinvointivaltioiden harjoittamaa koulutuspolitiikkaa. Hallitukset ovat luopumassa koulutuksesta osana yhteiskunta- ja sosiaalipolitiikan harjoittamista ja siirtymässä yksilöllisen oppimisen näkökulmaan ennen kaikkea hallinnan strategiana. Laajemmin kyseessä on yhteiskunta- ja koulutuspoliittinen murros, jossa koulutuksen nimiin vannonut vanha, paljolti sosiaalidemokraattinen hyvinvointipolitiikka muuntuu oppimisen nimiin vannovaksi uusliberaalia hyvinvointireformia mukailevaksi markkinamalliksi. Oppimisesta tulee yksilön oma asia, hänen henkilökohtainen sosiaalisen ja kulttuurisen selviämisensä asia, ei enää yhteiskuntapoliittisen päätöksenteon asia. Samalla siirrytään kohti aikuisopiskelun markkinoita. Puhutaan sitten aikuisopiskelun "kvasimarkkinoista" tai "hallinnoiduista markkinoista", noilla markkinoilla hallituksilla säilyisi edelleen jossakin määrin valvova roolinsa, mutta jalukselle nostetaan uudet uljaat yksilöt, jotka itse tekevät omat valintansa ja sijoituksensa omilla riskeillään. Siirrymme kohden yksilöllisen pakkovalinnan yhteiskuntaa, jossa yksilöt ovat yksin vastuussa niin menestymisestään kuin menestymättömyydestään.

Elinikäinen oppiminen ei näinkään tarkasteltuna ole vain semanttinen, retorinen, käsitteellinen tai merkityksetön muutos, vaan se on reaalisesti viemässä politiikan painopistettä pois yhteiskunnallisesti tai yhteisöllisesti organisoidusta aikuiskoulutuksesta. Griffin kutsuu uutta mallia "oppimisen yksilöllisen kulutuksen malliksi”. Tämä siir- tymä kantaa harteillaan ainakin seuraavia asioita (Griffin 1999a, 446-447; Rinne 2003a):

\section{Asetelma 1. OPPIMINEN YKSILÖLLISENÄ KULUTUKSENA}

Oppiminen ei ole enää palautettavissa koulutuksen hankkimiseen.

Oppiminen kytkeytyy enemmänkin ihmisten elämäntyyleihin kuin koulutukseen.

Oppiminen on vahvasti kulttuurinen näkökanta.

- Oppiminen kytkeytyy yksilön toiminnan mielekkyyteen ja yksilöiden elämismaailmaan kuin institutionaalisiin koulutusjärjestelmiin.

Oppimisen suhteen valtiosta on tullut enemmän strategi kuin politiikantekijä.

Oppiminen nähdään voimakkaasti yksilöiden kulutuksena.

Oppimisen nähdään tapahtuvan kvasimarkkinoilla, ei niinkään klassisilla vapailla markkinoilla.

Oppimisessa tärkeämpää on korostaa oppimistoimintojen johtamista ja hallinnointia kuin niiden ohjaamista ja kontrollointia.

- Oppimisessa korostetaan yksilöiden elämän integroitumista kokonaisuudeksi

sosiaalisessa, taloudellisessa, uudelleenluovassa ja vapaa-ajan toiminnoissa eikä jaeta yksilöiden elämää julkiseen ja yksityiseen.

\section{Kädetkö pystyyn voimattomuuden edessä?}

Jos jotakin tällä hetkellä aikuiskoulutustutkimuksessa tulisi tutkia, niin tätä yllä luonnehdittua epistomologista historiallista siirtymää ja tämän murroksen merkitystä yksittäisille ihmisille, ryhmille, yhteiskuntaluokille ja kansakunnille. Kyseessähän on perimmältään kokonaisia koulutusinstituutioita, niiden olemassaoloa ja olomuotoa järisyttävä muutos, jonka seuraamukset pitäisi ymmärtää niin globaaleissa, kansallisissa kuin lokaaleissa sosiaalisissa ja kulttuurisissa yhteyksissään.

Aikuiskoulutuksen ja elinikäisen oppimisen muuttuvan aseman, sen suomien mahdollisuuksien ja rajojen ymmärtäminen ei voi olla yksittäisen tutkimuksen tai edes yksittäisen tutkijan elämäntyön asia. Se vaatii tutkimusyhteisöä ja jaettua voimaa ja uskallusta asettaa oikeita, tärkeitä ja usein vaikeita kysymyksiä ja se edellyttää pelo- 
tonta ja vilpitöntä mieltä etsiä noihin kysymyksiin perusteltuja vastauksia. Tämä ei välttämättä tee tutkijan työstä helppoa, sujuvaa tai näyttävää. Se ei useinkaan tuota joukoittain esityksiä, sepitteitä ja tuotoksia eikä palkitse tutkijaa rahoittajien, tilaajien tai toimeksiantajien palkinnoin. Mutta meillä ei oman arvokkuutemme nimissä ole yksinkertaisesti varaa nostaa käsiämme voimattomina pystyyn edes uuden uljaan ihmisen aikakaudella.

\section{Lähteet}

Ball, S. (2009). Lifelong learning, Subjectivity and the totally pedagogised society. In M. A. Peters, A. C. Besley, M. Olssen, S. Maurer \& S. Weber (Eds.) Governmentality studies in education. Sense Publishers, 201-216.

Bauman, Z. (2005). Learning to walk in quicksands. Paper presented in the NERA Congress, University of Oslo, Norway, March 1012, 2005.

Coffield, F. (2000). Differing visions of a learning society: research findings, Volume 2. Bristol: The Policy Press.

Green, A. (2000). Lifelong learning and the learning society: Different European models of organization. In A. Hodgson (Ed.) Policies, politics and the future of lifelong learning. London: Kogan Page, 35-49.

Griffin, C. (1999a). Lifelong learning and social democracy. International Journal of Lifelong Education 18(5), 329-342.

Griffin, C. (1999b). Lifelong learning and welfare reform. International Journal of Lifelong Education 18 (6), 431-452.

Heikkinen, A. (2007). Fragmentation of adult education research. In R. Rinne, A. Heikkinen \& P. Salo (eds.) Adult education - Liberty, fraternity, equality? Nordic views on lifelong learning. Finnish Educational Research Association: Research in educational sciences 28. 83-102.

Huuhka, K. (1955). Talonpoikaisnuorison koulutie. Tutkimus talonpoikaisnuorison koulunkäynnistä ja siihen vaikuttaneista sosiaalisista tekijöistä Suomessa 1910-1950. Helsinki: Suomen historiallinen seura - Historiallisia tutkimuksia XLIII.

Instance, D. (2003). Schooling and lifelong learning: Insights from OECD Analysis. European
Journal of Education 38 (1), 85-98.

Järvinen, T. \& Vanttaja, M. (2001). Koulutusta osallistujien ehdoilla? Työvoimapoliittisen aikuiskoulutuksen vaihtoehtoisia suuntia.

Teoksessa T. Ruoholinna (toim.) Tarkasteluja aikuiskoulutuksen kentiltä. Turku: Turun yliopiston kasvatustieteiden tiedekunnan julkaisuja A:193, 103-115.

Nordhaug, O. (1986). Adult education in the welfare state: institutionalization of social commitment. International Journal of Lifelong Education 5 (1), 45-57.

OECD (2003). Beyond rhetoric: adult learning policies and practices. Paris: OECD.

Rinne, R. (2008). The growing supranational impacts of the OECD and the EU on national educational policies, and the case of Finland. Policy Futures in Education 6 (6), 665-680.

Rinne, R. (2003a). Arjen, työn ja kulttuuristen merkitysten jäljillä: haasteita 2000-luvun aikuiskoulutustutkimukselle. Teoksessa J. Manninen \& al. (toim.) Aikuiskasvatus tutkijoiden silmin. Helsinki: Kansanvalistusseura, 9-40.

Rinne, R. (2003b). Uusliberaali ajattelutapa on pesiytynyt suomalaiseenkin koulutuspolitiikkaan. Aikuiskasvatus 23 (2), 152-157.

Rinne, R. \& Kivinen, O. (1995) Mitä aikuiskasvatustutkimus on? Aikuiskasvatus 15(3), 255-264.

Rubenson, K. (in press) OECD Education policies and world hegemony.

Ruoholinna, T. \& Rinne, R. (2001). Tärkeä, tärkeämpi, tärkein - saatteeksi aikuiskoulutuksen kentille. Teoksessa T. Ruoholinna (toim.) Tarkasteluja aikuiskoulutuksen kentiltä. Turku: Turun yliopiston kasvatustieteiden tiedekunnan julkaisuja A:193, 5-13.

Schuller, T. (2004). International policy research: 'evidence' from CERI/OECD. Paper presented in European Conference on Education Research, Crete, September 2004.

Vaherva, T. (1986). Aikuiskoulutuksen kehittäminen ja kasvatustieteellinen tutkimus. Aikuiskasvatus 6 (6), 486-491.

Vanttaja, M. (1993). Aikuiskasvatuksen tutkimus Suomessa. Aikuiskasvatuksen historiallinen muotoutuminen ja tutkimuksen painopisteet vuosina 1970-1990. Kasvatustieteen pro gradu -tutkielma. Turku: Turun yliopisto, Kasvatustieteiden laitos. 